Research Note

\title{
Release of Biologically Active Peptides from Grape Juice by Oenococcus oeni Isolated from Argentine Wine
}

\author{
María Gilda Stivala, ${ }^{1}$ Gisselle Raquel Apud, ${ }^{1}$ and Pedro Aredes-Fernández ${ }^{1 *}$
}

\begin{abstract}
The increase in biologically active peptides after proteolytic activity of Oenococcus oeni $\mathrm{X}_{2} \mathrm{~L}$ was studied in grape juice medium (GJM) and in GJM fermented with Saccharomyces cerevisiae mc2. Sequential inoculation of $O$. oeni $\mathrm{X}_{2} \mathrm{~L}$ with proteolytic activity in GJM before ("I" medium) and after ("F" medium) yeast fermentation allowed peptide release. In the "I" medium, bacterial proteolytic activity $(0.083 \mathrm{mM})$ released $3.88 \mathrm{mg}$ nitrogen $(\mathrm{N})$ of peptides per liter and produced an increase of $203.39 \mu \mathrm{mol} / \mathrm{L}$ in the ferric reducing antioxidant power (FRAP) and $16.49 \%$ in the angiotensin I-converting enzyme inhibitory (ACE-I) activity after $48 \mathrm{hrs}$ of incubation. In the "F" medium, a higher proteolytic activity was evidenced after $48 \mathrm{hrs}$ of incubation $(0.179 \mathrm{mM})$, releasing $0.87 \mathrm{mg} \mathrm{N}$ of peptides/L. The released peptides in the "F" medium produced an increase in ACE-I activity (22.15\%). Calculation of the specific activity (activity expressed per $\mathrm{mg} \mathrm{N}$ of peptide released) of FRAP, 1, 1-diphenyl-2-picrylhydrazyl scavenging, and ACE-I after $48 \mathrm{hrs}$ of incubation revealed a higher activity in the " $F$ " than in the "I" medium. This finding indicates a higher efficiency of the proteolytic system of $O$. oeni $\mathrm{X}_{2} \mathrm{~L}$ on grape juice proteins in the release of bioactive peptides after yeast growth.
\end{abstract}

Key words: biological activities, Oenococcus oeni, peptide, proteolysis, Saccharomyces cerevisiae, wine

During alcoholic fermentation (AF) in winemaking, Saccharomyces cerevisiae transforms grape juice sugars into ethanol and carbon dioxide. At the end of AF, lactic acid bacteria, mainly Oenococcus oeni, carry out malolactic fermentation (MLF), a process that produces the conversion of L-malic acid into L-lactic acid (Ribéreau-Gayon et al. 2000). The MLF produces stabilization, a reduction in acidity, and desirable wine aroma and flavor (Bartowsky 2014). Manca de Nadra et al. (1999, 2005), Aredes Fernández et al. (2011), and Apud et al. (2013a, 2013b) reported the effect of proteolytic activity of $O$. oeni $\mathrm{X}_{2} \mathrm{~L}$ on the macromolecular nitrogen $(\mathrm{N})$ fraction of wines, which favored peptide release with biological activities. Exoprotease of $O$. oeni was partially purified and characterized by Farías and Manca de Nadra (2000). Several authors reported that food peptides exhibit particular biological activity on human health (Tripathi and Vashishtha 2006, Yalçin 2006, Hartmann and Meisel 2007, Möller et al. 2008). Aredes Fernández et al. (2011) showed that the proteolytic activity expressed by $O$. oeni during sequential inoculation of the bacterium after yeast autolysis produced a

${ }^{1}$ Facultad de Bioquímica, Química y Farmacia, Universidad Nacional de Tucumán, Ayacucho 491, 4000, San Miguel de Tucumán, Argentina, Consejo Nacional de Investigaciones Científicas y Técnicas (CONICET), Argentina.

*Corresponding author (pedroaredes@fbqf.unt.edu.ar)

Acknowledgments: The authors wish to thank the Consejo Nacional de Investigaciones Científicas y Técnicas (CONICET) (Project 2014-2016 PIP N 627).

Manuscript submitted Dec 2016, revised Jan 2017, Mar 2017, Aug 2017, accepted Aug 2017

Copyright $(\subset 2018$ by the American Society for Enology and Viticulture. All rights reserved.

doi: 10.5344/ajev.2017.16119 decrease in the protein concentration and an increase in the concentration of free peptides with angiotensin I-converting enzyme inhibitory (ACE-I) and antioxidant activities. This finding confirms that bioactive peptides present multifunctional activities (Di Bernardini et al. 2011, Ko and Jeon 2013).

For a better understanding of the effect of proteolytic activity by $O$. oeni on natural substrates, the current study was performed using natural grape juice medium (GJM) to determine modifications in the $\mathrm{N}$ profile and biological activities during sequential inoculation of $O$. oeni $\mathrm{X}_{2} \mathrm{~L}$ in GJM fermented by $S$. cerevisiae mc2.

\section{Materials and Methods}

Microbial strains and culture conditions. S. cerevisiae mc2 isolated from Argentine wine (GenBank Data Library, accession number $\mathrm{FJ} 800031$ ) was grown at $30^{\circ} \mathrm{C}$ in yeast extract-peptone-dextrose broth (YPD) medium containing: yeast extract, $10 \mathrm{~g} / \mathrm{L}$; peptone, $20 \mathrm{~g} / \mathrm{L}$; and glucose, $20 \mathrm{~g} / \mathrm{L}$. $O$. oeni $\mathrm{X}_{2} \mathrm{~L}$ isolated from Argentine wine (Strasser de Saad and Manca de Nadra 1987) was grown at $30^{\circ} \mathrm{C}$ in De Man, Rogosa, and Sharpe (MRS) broth with $15 \%$ (v/v) tomato juice ( $\mathrm{pH} 4.8$ ).

Sequential cultures in liquid medium. $S$. cerevisiae mc2 cells were grown in YPD medium until the exponential growth phase, then washed with sterile saline solution and resuspended in GJM containing $57 \mathrm{~mL}$ grape juice/L, $10 \mathrm{~g}$ yeast extract/L, and $1 \mathrm{~mL}$ polysorbate $80 / \mathrm{L}, \mathrm{pH} 5.5$. Yeast cells were inoculated at $10^{8} \mathrm{CFU} / \mathrm{mL}$ in GJM and incubated at $30^{\circ} \mathrm{C}$. At $0 \mathrm{hr}$ ("I" medium) and after $24 \mathrm{hrs}$ ("F" medium), culture aliquots were used for viable cell counts on YPD-agar medium. Cells were removed from the "I" and the "F" media by centrifugation at 7,000 $\mathrm{g}$ for $10 \mathrm{~min}$, and supernatants were sterilized by filtration. Aliquots of these supernatants were stored at $-20^{\circ} \mathrm{C}$ for analytical determinations. 
An exponential culture of $O$. oeni $\mathrm{X}_{2} \mathrm{~L}$ grown in MRS broth was washed with a sterile saline solution, and cells were inoculated in $10 \mathrm{~mL}$ of sterile supernatants obtained from yeast cultures ("I" and "F" media) at a concentration of $10^{6} \mathrm{CFU} / \mathrm{mL}$ and incubated for $48 \mathrm{hrs}$ at $30^{\circ} \mathrm{C}$. At different times $(0,24$, and $48 \mathrm{hrs})$, viable cell counts were performed on MRS-agar plates, and aliquots of the bacterial cultures were stored at $-20^{\circ} \mathrm{C}$ for analytical determinations.

Proteolytic activity. O. oeni $\mathrm{X}_{2} \mathrm{~L}$ supernatants obtained at 0,24 , and $48 \mathrm{hrs}$ were used to determine proteolytic activity using autoclaved grape juice as a substrate. After $1 \mathrm{hr}$ of incubation at $30^{\circ} \mathrm{C}$, the reaction was stopped with $600 \mu \mathrm{L}$ of $24 \%(w / v)$ trichloroacetic acid (TCA). Controls were obtained by precipitation with TCA before incubation. Free amino acids and peptides were quantified in $0.2 \mathrm{~mL}$ TCA supernatant aliquots by adding $0.4 \mathrm{~mL}$ of Sn-ninhydrin reagent according to Method 1 by Doi et al. (1981).

Proteins. The determination of protein concentration was carried out by the Bradford method using a calibration curve prepared with known concentrations of bovine serum albumin. The results are expressed as milligrams of $\mathrm{N}$ per liter (mg N/L).

Peptides and amino acids. Total free amino acid concentration was quantified in supernatants according to Method 5 by Doi et al. (1981) using Cd-ninhydrin as the reagent. Determinations of free amino acids and peptides were carried out using Sn-ninhydrin as the reagent (Doi et al. 1981, Method 1). Peptides were estimated from the difference between the results obtained with Methods 1 and 5. Results are expressed in $\mathrm{mg} \mathrm{N} / \mathrm{L}$. L-leucine was used as the standard (14 $\mathrm{g} \mathrm{N} / 131.17$ $\mathrm{g}$ of leucine).

ACE-I activity. ACE-I activity was determined according to the method described by Cushman and Cheung (1971), and modified by Hernández-Ledesma et al. (2003). This technique is based on the quantification of hippuric acid formed by the reaction of hippuryl-histidyl-leucine with angiotensin I-converting enzyme (ACE) in the presence and/ or absence of an inhibitor. Absorbance was measured at 228 $\mathrm{nm}$, and activity is expressed as the percentage of ACE inhibition.

DPPH radical scavenging activity. The DPPH (1, 1-diphenyl-2-picrylhydrazyl) free radical scavenging capacity of the samples was determined according to Von Gadow et al. (1997), using ascorbic acid as positive control. The absorbance was measured at $517 \mathrm{~nm}$, and the results are expressed as the percentage of radical scavenging in samples.

Ferric reducing power. Total antioxidant capacity was determined by ferric reducing antioxidant power (FRAP) according to Benzie and Strain (1996). Absorbance was measured at $593 \mathrm{~nm}$. A standard curve was constructed using $\mathrm{FeSO}_{4}$ solution (100 to $\left.1,000 \mu \mathrm{mol} / \mathrm{L}\right)$. FRAP values are expressed as $\mathrm{FeSO}_{4}$ equivalents ( $\left.\mu \mathrm{mol} \mathrm{FeSO}_{4} / \mathrm{L}\right)$.

Statistical analyses. The means and reproducibility of data were calculated based on two independent experiments performed in triplicate. The experimental data were analyzed by one-way analysis of variance test. Variable means showing statistical significance were compared using Tukey's test
(Minitab student R12). All statements of significance are based on the 0.05 level of probability.

\section{Results and Discussion}

In GJM, $S$. cerevisiae mc2 reached a viable cell count of 8.27 Log CFU/mL after $24 \mathrm{hrs}$ of incubation (control) (Figure 1). In this medium, protein consumption and amino acid concentration increased by $7.04 \mathrm{mg} \mathrm{N} / \mathrm{L}$ and $2.06 \mathrm{mg} \mathrm{N} / \mathrm{L}$ after $24 \mathrm{hrs}$, respectively, whereas peptide concentration in the medium was not modified (Table 1). After this time, the microorganism reached the stationary growth phase, and no significant changes were detected in the concentration of $\mathrm{N}$ compounds. We concluded that lysis of the eukaryotic microorganism did not occur until $72 \mathrm{hrs}$ of incubation. Figure 2 shows that the viability of $O$. oeni $\mathrm{X}_{2} \mathrm{~L}$ in the "F" medium

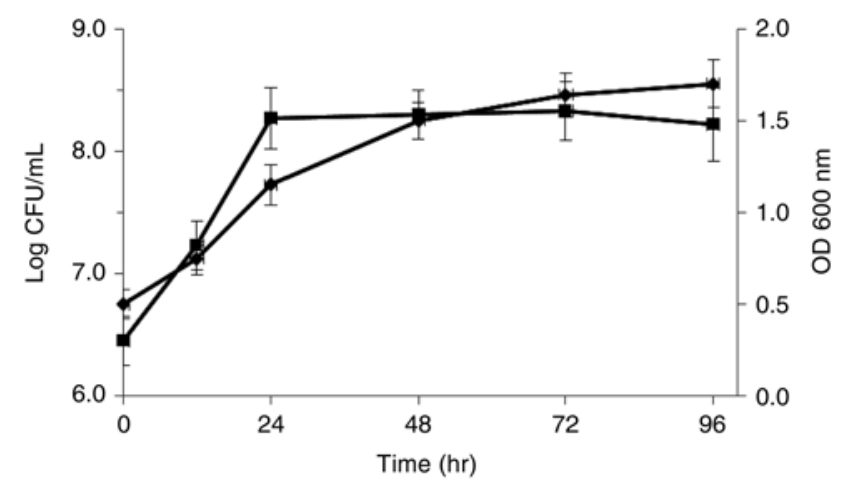

Figure 1 Growth of Saccharomyces cerevisiae mc2 in grape juice medium, expressed as Log CFU/mL ( $\bullet$ ) and optical density (४).

Table 1 Change in nitrogen $(\mathrm{N})$ compounds during growth of Saccharomyces cerevisiae mc2 in grape juice medium.

\begin{tabular}{lccc}
\hline $\begin{array}{l}\text { Time } \\
\text { (hr) }\end{array}$ & $\begin{array}{c}\text { Peptides } \\
(\mathbf{m g ~ N} / \mathbf{L})\end{array}$ & $\begin{array}{c}\text { Amino acids } \\
(\mathbf{m g ~ N} / \mathbf{L})\end{array}$ & $\begin{array}{c}\text { Proteins } \\
(\mathbf{m g ~ N} / \mathbf{L})\end{array}$ \\
\hline $\mathbf{0}$ & $0.93 \mathrm{a}^{\mathrm{a}}$ & $1.30 \mathrm{a}$ & $26.19 \mathrm{a}$ \\
$\mathbf{2 4}$ & $1.00 \mathrm{a}$ & $3.36 \mathrm{~b}$ & $19.15 \mathrm{~b}$ \\
$\mathbf{4 8}$ & $0.98 \mathrm{a}$ & $3.32 \mathrm{~b}$ & $17.32 \mathrm{c}$ \\
$\mathbf{7 2}$ & $0.97 \mathrm{a}$ & $3.25 \mathrm{~b}$ & $16.57 \mathrm{c}$ \\
\hline
\end{tabular}

avalues with the same letter in the same column are not significantly different $(p<0.05, \mathrm{n}=6)$.

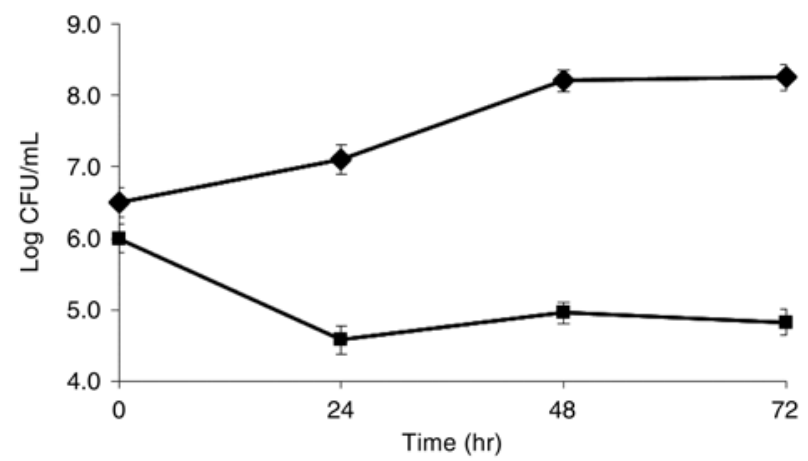

Figure 2 Viability of Oenococcus oeni $\mathrm{X}_{2} \mathrm{~L}$ in grape juice medium fermented with Saccharomyces cerevisiae mc2 ( $\bullet$ ) and nonfermented ( $\bullet$ ), expressed as Log CFU/mL. 
Table 2 Change in nitrogen $(\mathrm{N})$ compounds concentration, proteolytic activity, and specific activities (ferric reducing antioxidant power [FRAP]; 1, 1-diphenyl-2-picrylhydrazyl [DPPH]; and angiotensin I-converting enzyme inhibitory [ACE-I] activity) of Oenococcus oeni $\mathrm{X}_{2} \mathrm{~L}$ in grape juice medium unfermented ("I") and fermented ("F") with Saccharomyces cerevisiae mc2.

\begin{tabular}{|c|c|c|c|c|c|c|c|}
\hline \multirow[b]{2}{*}{$\begin{array}{l}\text { Medium/ } \\
\text { time (hr) }\end{array}$} & \multicolumn{3}{|c|}{ Nitrogenous compounds ${ }^{a}$} & \multirow[b]{2}{*}{$\begin{array}{c}\text { Proteolytic } \\
\text { activity (mM) }\end{array}$} & \multicolumn{3}{|c|}{ Specific activities $^{\mathrm{b}}$} \\
\hline & $\begin{array}{l}\text { Peptides } \\
\text { (mg N/L) }\end{array}$ & $\begin{array}{c}\text { Amino acids } \\
(\mathrm{mg} \mathrm{N} / \mathrm{L})\end{array}$ & $\begin{array}{l}\text { Proteins } \\
\text { (mg N/L) }\end{array}$ & & $\begin{array}{c}\text { FRAP } \\
(\mu \mathrm{M} \text { FeSO4/mg N) }\end{array}$ & $\begin{array}{c}\text { DPPH } \\
(\% / \mathrm{mg} \mathrm{N})\end{array}$ & $\begin{array}{c}\text { ACE-I } \\
(\% / \mathrm{mg} \mathrm{N})\end{array}$ \\
\hline \multicolumn{8}{|c|}{ Unfermented (“|l”) } \\
\hline 0 & $0.86 \mathrm{a}$ & $1.97 \mathrm{a}$ & $27.15 \mathrm{a}$ & $0.025 \mathrm{a}$ & - & - & - \\
\hline 24 & $3.38 \mathrm{~b}$ & $1.19 \mathrm{~b}$ & $21.68 b$ & $0.074 \mathrm{~b}$ & $285.27 \pm 27.05$ & $3.57 \pm 0.32$ & $15.97 \pm 1.35$ \\
\hline 48 & $3.88 \mathrm{c}$ & $0.97 \mathrm{~b}$ & 20.62 c & $0.083 \mathrm{c}$ & $207.05 \pm 20.20$ & $2.47 \pm 0.21$ & $17.63 \pm 1.54$ \\
\hline \multicolumn{8}{|c|}{ Fermented (“F”) } \\
\hline 0 & $1.00 \mathrm{a}$ & $2.94 \mathrm{a}$ & 19.39 a & - & - & - & - \\
\hline 24 & $1.97 \mathrm{~b}$ & $3.87 \mathrm{~b}$ & $15.28 \mathrm{~b}$ & $0.030 \mathrm{a}$ & $470.85 \pm 45.80$ & $14.48 \pm 1.21$ & $42.91 \pm 3.98$ \\
\hline 48 & $1.87 \mathrm{~b}$ & $3.92 \mathrm{~b}$ & $16.84 \mathrm{~b}$ & $0.179 \mathrm{~b}$ & $472.67 \pm 42.30$ & $13.86 \pm 1.15$ & $65.01 \pm 6.27$ \\
\hline
\end{tabular}

aValues with the same letter in the same column are not significantly different $(p<0.05, \mathrm{n}=6)$.

bSecific activities were determined as the ratio between the absolute value of the activity and the concentration of released peptides. Values are expressed as mean \pm standard deviation.

decreased $1.5 \log$ cycles after $48 \mathrm{hrs}$ of incubation. In the "I" medium, the bacterium was able to grow and reached a concentration of $8.20 \mathrm{Log} \mathrm{CFU} / \mathrm{mL}$ at the end of the exponential growth phase $(48 \mathrm{hrs})$. These results are in accordance with Nehme et al. (2010), who determined that the biomass of $O$. oeni $\mathrm{X}$ decreased in medium fermented with $S$. cerevisiae. Farías et al. (2003) reported that $O$. oeni $\mathrm{X}_{2} \mathrm{~L}$ cells decreased $0.84 \log$ cycles after $72 \mathrm{hrs}$ in medium prefermented with Hanseniaspora uvarum ca12.

Table 2 shows that, in the "I" medium, proteolytic activity of $O$. oeni $\mathrm{X}_{2} \mathrm{~L}$ increased to $0.049 \mathrm{mM}$ and $0.083 \mathrm{mM}$ after 24 and $48 \mathrm{hrs}$ of incubation, respectively, while the protein concentration decreased after $24 \mathrm{hrs}$ with a peptide release of $2.52 \mathrm{mg} \mathrm{N} / \mathrm{L}$ and amino acid consumption of $0.78 \mathrm{mg} \mathrm{N} / \mathrm{L}$. After $48 \mathrm{hrs}$, the peptide concentration reached its maximum ( $3.88 \mathrm{mg} \mathrm{N} / \mathrm{L}$ ), but the amino acid $\mathrm{N}$ concentration was not altered. With respect to the "F" medium, proteolytic activity increased after 24 and $48 \mathrm{hrs}$ of incubation, reaching 0.030 and $0.179 \mathrm{mM}$, respectively. At $24 \mathrm{hrs}$ of incubation, protein $\mathrm{N}$ consumption was $4.11 \mathrm{mg} \mathrm{N} / \mathrm{L}$, with an increase in peptide and amino acid $\mathrm{N}$ concentration $(0.97 \mathrm{mg} \mathrm{N} / \mathrm{L}$ and $0.93 \mathrm{mg}$ N/L, respectively). Aredes Fernández et al. (2011) demonstrated that during sequential inoculation of O. oeni $\mathrm{X}_{2} \mathrm{~L}$ in synthetic wine medium and after autolysis of $S$. cerevisiae $\mathrm{mc}$, bacterial proteolytic activity reached values similar to those ascertained in the current study. Apud et al. (2013a) determined that $O$. oeni $\mathrm{m} 1$ expressed proteolytic activity that produced the release of peptides from a wine protein fraction.

Figures 3, 4, and 5 show the changes of FRAP, DPPH, and ACE-I activities, respectively. In the medium fermented by $S$. cerevisiae, peptide release was not evidenced and no significant changes were detected in either of the biological activities determined during the entire incubation time ( $48 \mathrm{hrs}$ ). However, Alcaide-Hidalgo et al. (2007) found that peptides released during accelerated autolysis of $S$. cerevisiae produced an increase in antioxidant activity. Similar results were obtained by Aredes Fernández et al. (2011), who reported that after accelerated yeast autolysis, the peptide release produced

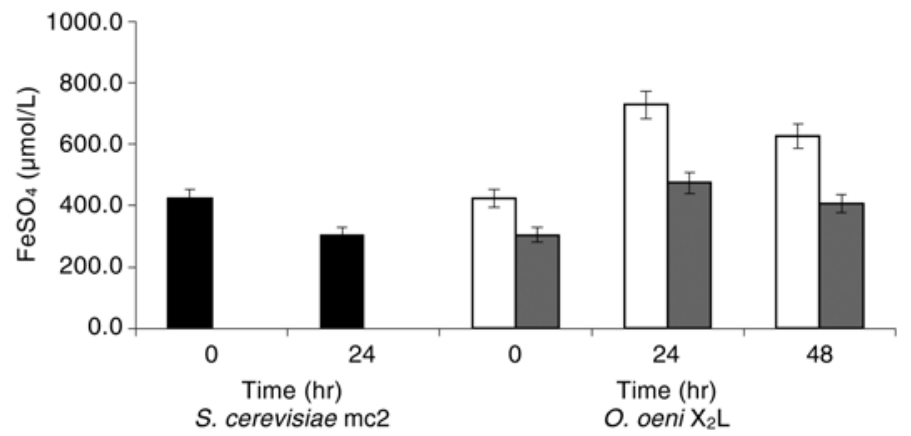

Figure 3 Change in antioxidant activity determined by reduction of the $\mathrm{Fe}^{+3}$-TPTZ complex (ferric reducing antioxidant power; FRAP) in grape juice medium during growth of Saccharomyces cerevisiae mc2 (black bars) and Oenococcus oeni $\mathrm{X}_{2} \mathrm{~L}$ before (white bars) and after (gray bars) fermentation with the eukaryotic microorganism.

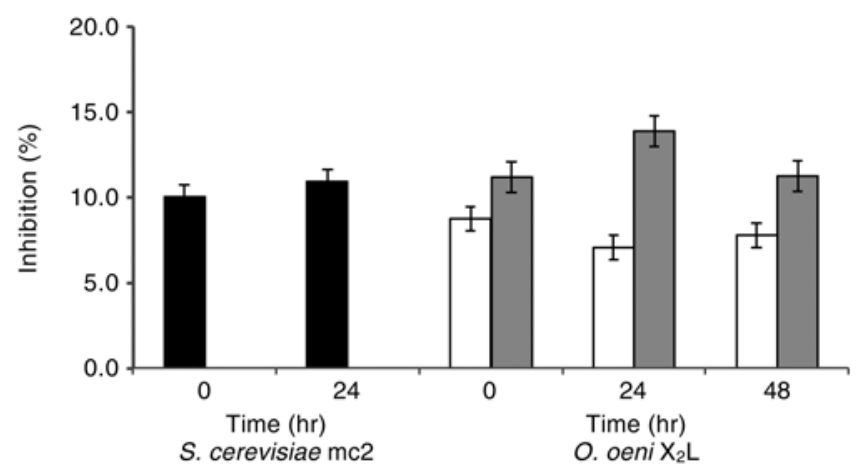

Figure 4 Change in antioxidant activity determined by radical scavenging activity (1, 1-diphenyl-2-picrylhydrazyl; DPPH) in grape juice medium during growth of Saccharomyces cerevisiae mc2 (black bars) and Oenococcus oeni $\mathrm{X}_{2} \mathrm{~L}$ before (white bars) and after (gray bars) fermentation with the eukaryotic microorganism.

an increase in FRAP activity. After inoculation of $O$. oeni in "I" medium, an increase in FRAP activity of $305.07 \mu \mathrm{mol} / \mathrm{L}$ was observed after $24 \mathrm{hrs}$ of incubation. Nevertheless, no significant changes were detected in DPPH activity. The ACE-I activity increased $16.49 \%$ after $48 \mathrm{hrs}$ incubation. In the " $\mathrm{F}$ " 


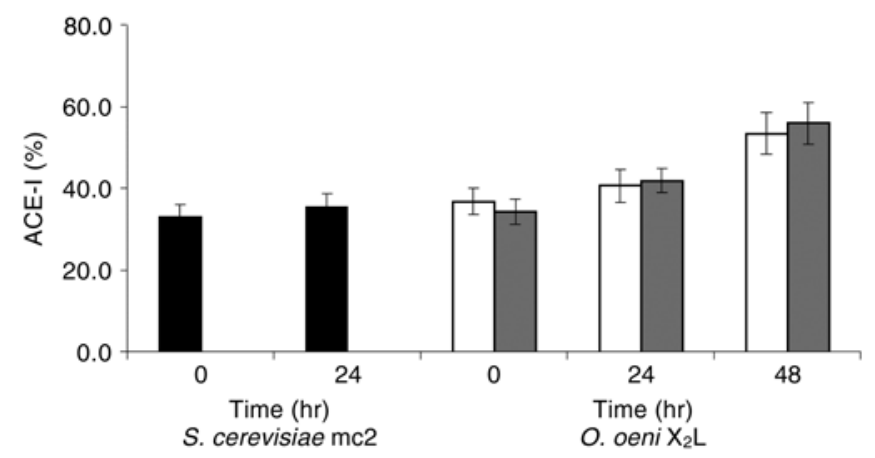

Figure 5 Change in angiotensin I-converting enzyme inhibitory (ACE-I) activity in grape juice medium during growth of Saccharomyces cerevisiae mc2 (black bars) and Oenococcus oeni $\mathrm{X}_{2} \mathrm{~L}$ before (white bars) and after (gray bars) fermentation with the eukaryotic microorganism.

medium, an increase in FRAP activity of $169.48 \mu \mathrm{mol} / \mathrm{L}$ was observed after $24 \mathrm{hrs}$ of incubation, and an increase in ACEI activity of $22.15 \%$ was shown after $48 \mathrm{hrs}$; however, no significant difference was detected in DPPH activity. Aredes Fernández et al. (2011) determined that peptides released by $O$. oeni $\mathrm{X}_{2} \mathrm{~L}$ after accelerated yeast autolysis showed a slightly higher antioxidant activity (FRAP and DPPH), but ACE-I activity was four-fold lower compared to the current study. This finding is probably because peptides released from the grape juice proteins present higher ACE-I activity compared to the peptides released from yeast autolysis. Adding to the known beneficial biological activities of peptides from wine or yeast autolysis, our results confirm the important role of peptides in such activities in fermented grape juice. Peptides from wine, grape juice, or yeast autolysis present beneficial biological activities (Touyz 2004, Alcaide-Hidalgo et al. 2007, Aredes Fernández et al. 2011, Jang and Lee 2011, Apud et al. 2013a, 2013b).

To establish the relationship between the concentration of peptides released and antioxidant and ACE-I activities assayed, specific antioxidant and ACE-I activities were determined, as shown in Table 2. In the "F" medium, O. oeni exhibited higher specific FRAP, DPPH, and ACE-I activities than in the "I" medium, despite the decrease in both bacterial viability and peptide release with respect to the "I" medium (Table 2). The higher specific activities observed in the " $F$ " medium would be related to the greater efficiency of the proteolytic system of $O$. oeni to release bioactive peptides after yeast fermentation. These results suggest that peptides released from a natural protein source such as grape juice would have higher antihypertensive activity than those obtained from yeast autolysis. Although further studies are necessary to elucidate the mechanisms involved in the biological activities, our study confirms the efficiency of the proteolytic system of $O$. oeni $\mathrm{X}_{2} \mathrm{~L}$ to release peptides with ACE-I and antioxidant activities.

\section{Conclusions}

Growth of O. oeni $\mathrm{X}_{2} \mathrm{~L}$ in GJM or in GJM fermented with $S$. cerevisiae $\mathrm{mc} 2$ produced an increase in antioxidant (deter- mined with FRAP and DPPH scavenging assays) and ACE-I activities. This behavior is most likely related to the presence of bacterial proteolytic activity that enabled the release of bioactive peptides. The yeast-fermented medium demonstrated higher biological activities produced through the presence of released peptides by $O$. oeni $\mathrm{X}_{2} \mathrm{~L}$ compared with the nonfermented medium. This effect is probably a result of a different exoprotease (stress exoprotease) expressed under unfavorable environmental conditions. Presence of this enzyme enables peptide release with higher and/or more specific biological activities. Our results confirm the important role of proteins derived from grape juice in the release of peptides with beneficial biological activities.

This study contributes to a current but underexplored topic by providing new knowledge on the role of a proteolytic $O$. oeni strain isolated from Argentine wines in the release of the bioactive peptides that would enable incorporation of additional value to regional wines.

\section{Literature Cited}

Alcaide-Hidalgo JM, Pueyo E, Polo MC and Martínez-Rodríguez AJ. 2007. Bioactive peptides released from Saccharomyces cerevisiae under accelerated autolysis in a wine model system. J Food Sci 72:M276-M279.

Apud GR, Rodríguez Vaquero MJ, Rollan G, Stivala MG and Aredes Fernández P. 2013a. Increase in antioxidant and antihypertensive peptides from Argentinean wines by Oenococcus oeni. Int J Food Microbiol 163:166-170.

Apud GR, Stivala MG, Aredes Fernández P and Rodríguez Vaquero MJ. 2013b. Proteolytic activity of Oenococcus oeni enables the increase in antioxidant and antihypertensive activities from wine. Curr Pharm Biotechnol 14:809-813.

Aredes Fernández PA, Stivala MG, Rodríguez Vaquero MJ and Farías ME. 2011. Increase in antioxidant and antihypertensive activity by Oenococcus oeni in a yeast autolysis wine model. Biotechnol Lett 33:359-364.

Bartowsky EJ. 2014. Wines: Malolactic fermentation. In Encyclopedia of Food Microbiology, Vol 3. 2nd ed. Batt CA and Tortorello ML (eds.), pp. 800-804. Elsevier, Berkshire, UK.

Benzie IFF and Strain JJ. 1996. The ferric reducing ability of plasma (FRAP) as a measure of "antioxidant power": The FRAP assay. Anal Biochem 239:70-76.

Cushman DW and Cheung HS. 1971. Spectrophotometric assay and properties of the angiotensin-converting enzyme of rabbit lung. Biochem Pharmacol 20:1637-1648.

Di Bernardini R, Harnedy P, Bolton D, Kerry J, O’Neill E, Mullen AM and Hayes M. 2011. Antioxidant and antimicrobial peptidic hydrolysates from muscle protein sources and by-products. Food Chem 124:1296-1307.

Doi E, Shibata D and Matoba T. 1981. Modified colorimetric ninhydrin methods for peptidase assay. Anal Biochem 118:173-184.

Farías ME and Manca de Nadra MC. 2000. Purification and partial characterization of Oenococcus oeni exoprotease. FEMS Microbiol Lett 185:263-266.

Farías ME, Aredes Fernández PA, Sosa OA and Manca de Nadra MC. 2003. Influence of non-Saccharomyces yeast growth on the metabolism of nitrogenous compounds in lactic acid bacteria from wine. Lat Am Appl Res 33:231-234.

Hartmann R and Meisel H. 2007. Food-derived peptides with biological activity: From research to food applications. Curr Opin Biotech $18: 163-169$ 
Hernández-Ledesma B, Martín-Álvarez PJ and Pueyo E. 2003. Assessment of the spectrophotometric method for determination of angiotensin-converting-enzyme activity: Influence of the inhibition type. J Agric Food Chem 51:4175-4179.

Jang JH and Lee JS. 2011. Antihypertensive angiotensin I-converting enzyme inhibitory activity and antioxidant activity of Vitis hybridVitis coignetiae red wine made with Saccharomyces cerevisiae. Mycobiology 39:137-139.

Ko SC and Jeon YJ. 2013. Marine peptides for preventing metabolic syndrome. Curr Protein Pept Sci 14:183-188.

Manca de Nadra MC, Farías ME, Moreno-Arribas V, Pueyo E and Polo MC. 1999. A proteolytic effect of Oenococcus oeni on the nitrogenous macromolecular fraction on red wine. FEMS Microbiol Lett 174:41-47.

Manca de Nadra MC, Farías ME, Pueyo E and Polo MC. 2005. Protease activity of Oenococcus oeni viable cells on red wine nitrogenous macromolecular fraction in presence of $\mathrm{SO}_{2}$ and ethanol. Food Control 16:851-854.

Möller NP, Scholz-Ahrens KE, Roos N and Schrezenmeir J. 2008. Bioactive peptides and proteins from foods: Indication for health effects. Eur J Nutr 47:171-182.
Nehme N, Mathieu F and Taillandier P. 2010. Impact of the co-culture of Saccharomyces cerevisiae-Oenococcus oeni on malolactic fermentation and partial characterization of a yeast-derived inhibitory peptidic fraction. Food Microbiol 27:150-157.

Ribéreau-Gayon P, Dubourdieu D, Donèche B and Lonvaud A. 2000. Handbook of Enology. The Microbiology of Wine and Vinifications. Wiley, West Sussex, England.

Strasser de Saad AM and Manca de Nadra MC. 1987. Isolation and identification of lactic acid bacteria from Cafayate (Argentina) wines. Microbiol Aliments Nutr 5:45-49.

Touyz RM. 2004. Reactive oxygen species, vascular oxidative stress, and redox signaling in hypertension: What is the clinical significance? Hypertension 44:248-252.

Tripathi V and Vashishtha B. 2006. Bioactive compounds of colostrum and its application. Food Rev Int 22:225-244.

von Gadow A, Joubert E and Hansmann CF. 1997. Comparison of the antioxidant activity of aspalathin with that of other plant phenols of Rooibos tea (Aspalathus linearis), $\alpha$-tocopherol, BHT, and BHA. J Agric Food Chem 45:632-638.

Yalçin AS. 2006. Emerging therapeutic potential of whey proteins and peptides. Curr Pharm Des 12:1637-1643. 